\title{
Review \\ Axillary Bud Fate Shapes Plant Architecture in Horticultural Crops
}

\author{
Javier Andrés $(\mathbb{D}$ and Elli Koskela *
}

Citation: Andrés, J.; Koskela, E. Axillary Bud Fate Shapes Plant Architecture in Horticultural Crops.

Horticulturae 2022, 8, 130.

https://doi.org/10.3390/

horticulturae 8020130

Academic Editor: Luigi De Bellis

Received: 15 December 2021

Accepted: 25 January 2022

Published: 31 January 2022

Publisher's Note: MDPI stays neutral with regard to jurisdictional claims in published maps and institutional affiliations.

Copyright: (C) 2022 by the authors. Licensee MDPI, Basel, Switzerland. This article is an open access article distributed under the terms and conditions of the Creative Commons Attribution (CC BY) license (https:// creativecommons.org/licenses/by/ $4.0 /)$.

\author{
Department of Agricultural Science, Faculty of Agriculture and Forestry, University of Helsinki, \\ 00014 Helsinki, Finland; javier.andresjimenez@helsinki.fi \\ * Correspondence: elli.koskela@helsinki.fi; Tel.: +358-50-347-2582
}

\begin{abstract}
Above-ground plant architecture is dictated to a large extent by the fates and growth rates of aerial plant meristems. Shoot apical meristem gives rise to the fundamental plant form by generating new leaves. However, the fates of axillary meristems located in leaf axils have a great influence on plant architecture and affect the harvest index, yield potential and cultural practices. Improving plant architecture by breeding facilitates denser plantations, better resource use efficiency and even mechanical harvesting. Knowledge of the genetic mechanisms regulating plant architecture is needed for precision breeding, especially for determining feasible breeding targets. Fortunately, research in many crop species has demonstrated that a relatively small number of genes has a large effect on axillary meristem fates. In this review, we select a number of important horticultural and agricultural plant species as examples of how changes in plant architecture affect the cultivation practices of the species. We focus specifically on the determination of the axillary meristem fate and review how plant architecture may change even drastically because of altered axillary meristem fate. We also explain what is known about the genetic and environmental control of plant architecture in these species, and how further changes in plant architectural traits could benefit the horticultural sector.
\end{abstract}

Keywords: plant architecture; tree architecture; axillary meristem fate; genetic regulation; breeding

\section{Introduction}

Plant architecture determines resource allocation within a plant and therefore has a great influence on, for example, harvest index, yield potential, cultural practices and even the choice of mechanical versus manual harvesting. Cultural practices, such as pruning or the use of growth control substances to regulate plant architecture, may be quite costly. Therefore, improving plant architectural traits via breeding is a desirable approach.

Breeding for improved plant architecture does not necessarily require detailed knowledge on the identities of the genes controlling the traits. This is exemplified by the success of the "Green Revolution" cereal cultivars, whose breeding was based on conventional hybridization and selection, ideotype breeding, and the introduction of recessive "dwarfing" loci from exotic germplasm. Combining these breeding strategies during the Green Revolution led to the doubling in the yield potential in rice and wheat [1]. However, understanding how individual genes and entire genetic pathways regulate plant architecture, especially in combination with environmental conditions, would make further improvements in plant architecture much easier.

The fundamental above-ground plant form is endogenously dictated at the shoot apical meristem (SAM), which gives rise to phyllotactic patterning, i.e., the arrangement of leaves (recently reviewed in [2]); each leaf is accompanied by an axillary meristem (AXM), located at leaf axil (for a review on AXM initiation, see, e.g., [3]). The fates and relative growth rates of different meristems on the plant depend on both endogenous and exogenous factors, and determine the final form of plant architecture. SAMs can either keep on producing new vegetative plant tissues or, when induced to flower, differentiate into inflorescence meristems. AXMs can develop into vegetative or generative branches, or remain dormant. Depending on the plant species, the fates of different meristems are 
determined by endogenous or exogenous signals, or a mixture of both (reviewed in [4]). The major endogenous signal regulating AXM fate is apical dominance, i.e., the inhibitory effect exerted by the SAM over AXMs (processes related to apical dominance are reviewed in Schneider et al. (2019)). A change in the strength of apical dominance has major influences on plant form, as exemplified by the domestication of maize (see Section 2.1). However, in some plant species, the role of apical dominance is not that strong and other factors regulate axillary bud $(\mathrm{AXB})$ fate, as seen with the strawberry (see Section 2.4 on the regulation of the strawberry plant architecture).

In this review, we select a number of important crop species as examples of how changes in plant architecture affect the cultivation practices of the species. We focus specifically on the determination of AXM fate and review how plant architecture may change even drastically as a result of altered AXM fate. We also explain what is known about the genetic and environmental control of plant architecture in these species, and how further changes in plant architectural traits could benefit the horticultural sector. The plant species were selected so as to highlight known different genetic mechanisms controlling plant architecture and to include both annual and perennial, woody and herbaceous crops.

\section{Plant Architecture in Selected Crop Species}

\subsection{Maize}

The modern maize (Zea mays L. ssp. mays) cultivars display plant architecture well suited for high-density planting and mechanical harvesting; the cultivated maize typically has a pronounced main culm (stem), with two or three short primary lateral (axillary) branches midway along the main stem producing terminal female inflorescences, or ears. The main stem itself carries a terminal male inflorescence, or a tassel. The plant architecture of modern maize differs starkly from that of its wild ancestor, the teosinte (Zea mays ssp. parviglumis), in which the majority of $\mathrm{AXBs}$ on the main stem develop into elongated primary lateral branches. The primary lateral branches terminate in male inflorescences, while female inflorescences are borne on leaf axils of secondary branches [5,6].

The extensive phenotypical differences between modern maize and the teosinte can be attributed to five major-effect QTLs [7], one of which affects the strength of apical dominance and inflorescence sex on the primary lateral branches [8]. This QTL, teosinte branched 1 (tb1), was already characterized 60 years ago as a recessive mutant of modern maize, with extensive effects on plant architecture [9], and a general function in regulating AXM fate [8]. The molecular characterization of the $t b 1$ locus revealed a single gene active in growth-arrested AXBs and in stamens of ear primordia and expressed at a higher level in modern maize than in teosinte $[6,10]$. Later, $t b 1$ was shown to belong to the TCP (for TB1, CYCLOIDEA and PROLIFERATING CELL FACTORS) family of plant-specific transcription factors with the non-canonical basic-helix-loop-helix structure that have general functions in regulating cell division and growth [11].

The causative mutations differentiating the recessive teosinte $t b 1$ allele and the dominant maize TB1 do not reside within the coding sequence, but rather in distant $5^{\prime}$-upstream regulatory sequences [12]. These mutations were identified as two independent transposable element (TE) insertions $64-69 \mathrm{~kb}$ and 58-64 kb upstream of the TB1 locus that control maize basal branching and ear phenotype, respectively. Interestingly, the TE insertions did not disturb the ancestral gene function, but rather resulted in a gain-of-function mutation that enhances the expression of the target gene [13].

How TB1 in maize or its homologs in other species control plant architecture is not fully resolved. However, studies taking advantage of phenotypically well-characterized maize mutants have started to reveal a regulatory network, in which TB1 acts as the key regulator (Figure 1). The maize mutants tassels replace upper ears1 (tru1; [14]) and grassy tillers1 ( $g t 1$; [15]) have phenotypes partially resembling those of $t b 1$; tru1 mutants have increased branching in the upper parts of the stem and bear tassel-like upper ears while $g t 1$ mutants produce tillers profusely. The identity of $g t 1$ was elucidated by [16], who showed that the gene encodes a class I homeodomain leucine zipper transcription factor, whose activity 
depends on $t b 1$. Furthermore, studies in teosinte and sorghum (Sorghum bicolor) suggest that $t b 1$ and gt 1 activities respond to changes in light quality and are involved in the shade avoidance response mediated by the phytochrome signal transduction pathway [16,17].

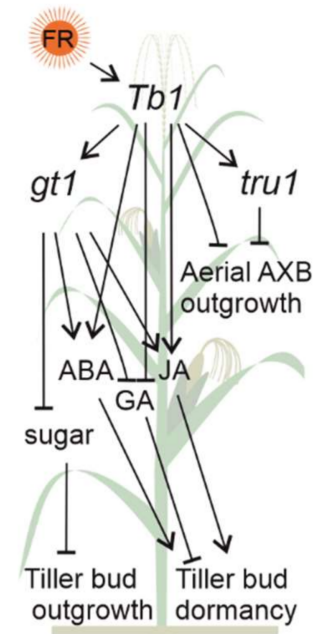

Figure 1. Regulation of maize plant architecture. TB1 regulates the outgrowth of aerial axillary buds and tillers via tru1 and $g t 1$, respectively. In addition, TB1 directly regulates the abscisic acid (ABA), gibberellic acid (GA) and jasmonic acid (JA) hormonal pathways to control tiller bud outgrowth. The gt1-mediated route involves a sugar signaling pathway. FR = far red. Data adapted from [18] under CC-BY License (http:/ / creativecommons.org/liceses/by/4.0/, accessed on 28 January 2022).

The tru1 gene acts downstream of $t b 1$, encodes an ankyrin-repeat domain protein with a BTB/POZ motif necessary for protein-protein interactions, and is directly activated by TB1 [19]. Using a combination of Chip-seq, RNA-seq, and metabolite measurements [18], recently showed that the three genes, namely $T B 1, g t 1$, and tru1, form a regulatory network in which TB1 is at the top of the hierarchy. In this network, the phytohormonal signaling pathways of jasmonic acid (JA) and abscisic acid (ABA) promote bud dormancy, and are upregulated by TB1 both directly and indirectly via GT1. In contrast, gibberellic acid (GA) biosynthesis and signaling were reduced in the tb1/gt1 mutants, suggesting that the genes may promote AXB dormancy by downregulating the GA pathway [18]. The sugar signaling pathway and especially the well-known indicator of sucrose availability, trehalose-6-phosphate (T6P), were indicated to have a role in determining AXB fate in maize. The accumulation of sugar metabolites, sucrose transporters and T6P was higher in non-dormant AXBs of $t b 1 / g t 1$ mutants than in dormant AXBs of TB1/GT1 plants, suggesting that increased sucrose levels may promote AXB outgrowth [18]. Finally, the TB1 allele of maize represses the expression of genes involved in the regulation of the cell cycle [20]. In summary, TB1 is a master regulator and integrator of multiple pathways, and changes in the activity of TB1 or its downstream genes provide an opportunity for modifying plant architecture.

As described above, the selection for the dominant TB1 allele in maize paved the way for the domestication of the species by altering plant architectural traits. At present, maize breeding programs still aim at developing cultivars even better suited for high-densityplanting by selection for reduced shade avoidance response, optimized plant height, and upright leaf angle. The elucidation of the functions of TB1 and other components of the pathway provide potential breeding targets for improving these traits, either by conventional breeding or by introducing new mutations using the CRISPR/Cas9 technology [21]. 


\subsection{Tomato}

The cultivated tomato (Solanum lycopersicon Mill.) is a nearly day-neutral plant that follows the sympodial growth pattern. The primary shoot produces 8-10 true leaves before terminating in an inflorescence meristem. The meristem located in the leaf axil immediately below the inflorescence meristem is often referred to as the sympodial meristem (SYM), to distinguish the SYM from the other AXMs on the plant. The distinction is important, because the fates of different meristems (primary, SYM, or AXM) are regulated by different genetic mechanisms, as exemplified by the phenotypes of tomato mutants with altered flowering time and/or plant architecture [22]. When the primary meristem terminates in an inflorescence meristem, the SYM continues the vegetative growth of the plant, forms three leaves and then itself terminates in an inflorescence meristem. The re-iterating pattern of two-to-three leaves and a terminal inflorescence repeats itself and, due to the very vigorous nature of the growth-continuing SYMs, produces a plant with an apparently upright stem [23]. It is important to notice that floral induction in tomatoes has a direct effect on plant architecture because inflorescence development leads to the loss of apical dominance and the release of SYM from growth arrest [22]. For this reason, most of this section deals with the molecular events leading to floral induction.

The repeated cycles of vegetative growth and inflorescence development result in a plant carrying trusses with unopened flowers, flowering trusses, and trusses with developing fruit at different stages of maturation. Due to uneven ripening, the tomato crop has been traditionally harvested by manual multi-pick harvest. Machine harvest has become possible only when recessive alleles of SELF PRUNING (SP) were introduced into the crop in the late 1950s to produce the determinate cultivar VF-145. $s p$ affects the overall plant architecture by gradually decreasing the number of leaves per sympodial unit from three to zero (Figure 2A), with the last sympodial unit terminating in an inflorescence [24]. This pattern of growth leads to a homogeneous fruit set and, consequently, uniform harvest time.

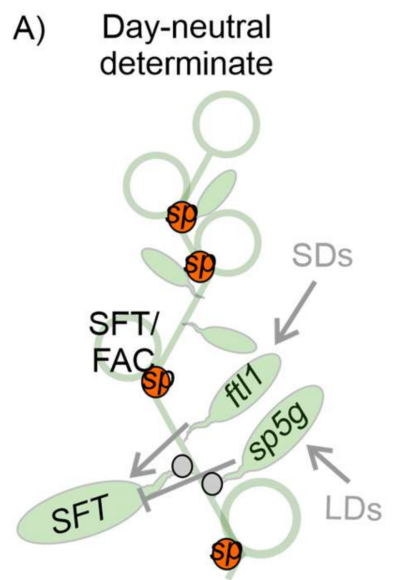

\section{B) Age-dependent pathway}

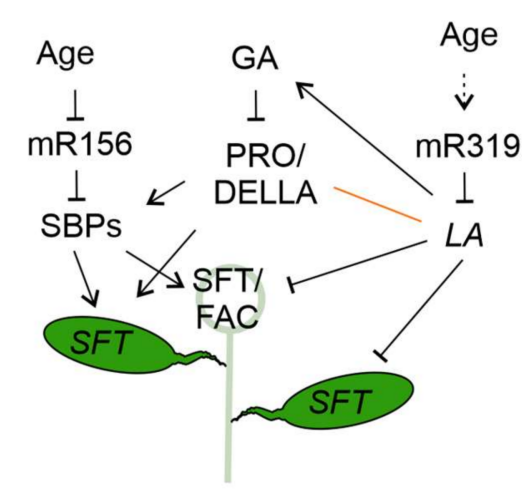

Figure 2. Tomato growth habits and regulation of flowering. (A) Day-neutral determinate cultivars bear non-functional alleles of $s p, s p 5 g$ and $f t l 1$; the $s p$ mutation changes the growth pattern from indeterminate to determinate by abolishing the meristem-maintaining function of $s p$ in SYMs. Mutations in $s p 5 g$ and $f t l 1$ render the plant nearly insensitive to photoperiodic cues. (B) Flowering in modern-day tomato cultivars is promoted by an age-dependent pathway that consists of a complex network that culminates in the regulation of the GA concentration [25]. SAMs are marked by open green circles, sympodial meristems by orange circles and axillary meristems by gray circles. Promotion is represented by arrows and repression by block arrows. SDs = short days; LDs = long days; $\mathrm{SFT}=$ single flower truss; FAC = florigen-activating complex; SBPs = squamosa protein binding-like; PRO/DELLA = Procera $/$ Della.

The identity of the SP gene was elucidated by [26], who showed that the determinate growth habit results from a mutation in the tomato functional ortholog of TERMINAL 
FLOWER1 (TFL1), a gene belonging to the CETS (for CENTRORADIALIS-TERMINAL FLOWER1-SELF PRUNING, after the first genes whose functions were characterized in plants) gene family. The expression domain of tomato $S P$ has been debated; some authors have described $S P$ to be widely expressed throughout plant development across all organ primordia [26], whereas others have found $S P$ activity confined to non-growing SYMs and AXMs [27]. Given that neither the $s p$ mutation nor silencing SP by RNAi result in defects in inflorescence or flower development nor changes the number of leaves produced in the primary shoots before floral initiation, the main function of $S P$ appears to be in the maintenance of the vegetative status of sympodial meristems.

Although $s p$ is by far the most important mutation introduced into tomato cultivars, other mutations affecting tomato plant architecture do exist. Another critical gene in shaping tomato plant architecture is SINGLE FLOWER TRUSS (SFT), whose mutation leads to late flowering, abnormal flower morphology and abolishes the normal sympodial growth pattern of tomato [28]. In sft plants, the primary shoot does not terminate in an inflorescence, but instead produces an indeterminate "vegetative inflorescence", which consists of a few flowers intervened by leaves $[28,29]$. The growth of the primary shoot is indeterminate, and the SYMs in sft plants are arrested in growth [28].

Interestingly, SFT encodes another CETS family member, the tomato ortholog of FLOWERING LOCUS T (FT, [22]), which is a well-characterized florigen with a universal flowering-promoting and growth-terminating function in plants [29]. Similarly to FT orthologs from other species, SFT is transcribed in leaves and stems and the mobile SFT protein is translocated to the shoot apical meristem [22], where it is hypothesized to compete with SP in binding to a specific set of proteins [30]. These proteins include 14-3-3 proteins and the tomato homolog of FLOWERING LOCUS D and, when bound to SFT, they form a florigen activation complex (FAC) [30].

Recently, [31] demonstrated that mutations in regulatory regions of the SFT paralog and floral repressor SELF-PRUNING 5G (SP5G) cause the nearly day-neutral flowering in the cultivated tomato, whose closest wild relatives are quantitative short-day plants. In wild species, SP5G is strongly expressed in leaf tissues under non-flowering-permissive photoperiods and is de-activated under conditions favoring flowering. The gene is expressed to a much weaker level in the cultivated tomato, but is not completely silenced, and it does confer a weak photoperiodic response under long-day conditions. Interestingly, mutating SP5G by CRISPR-Cas9 in cultivated tomato results in greatly accelerated flowering of the primary and axillary shoots under long-day conditions, but does not change the pattern of sympodial growth [31].

In wild, non-domesticated tomato species, photoperiod-sensitive flowering is caused by SP5G-mediated repression of SFT expression specifically under LD conditions. On the other hand, in wild tomato, SDs advance flowering by upregulating another SFT paralog and floral promoter, FLOWERING LOCUS T-LIKE1 (FTL1, [32]). FTL1, in turn, activates SFT1. In modern tomato cultivars, both SP5G and FTL1 bear mutations in their cis-regulatory and coding regions, respectively, abolishing their functions and leading to day-neutral flowering responses [31,32].

In the modern tomato, flowering is largely photoperiod-insensitive and floral induction takes place via an age-dependent pathway (Figure 2B). The pathway functions via two independent miRNA-mediated routes. As the plant ages, the floral-repressing function of mR156 gradually decreases, which results in the upregulation of SQUAMOSA PROTEIN BINDING-LIKE (SPL/SBP) transcription factors. SBPs, in turn, upregulate SFT in leaves and probably activate the FAC at the shoot apex to promote the expression of the floral meristem identity gene APETALA1. In addition to being regulated by mR156, SBPs are also regulated by DELLA proteins, a subgroup of GRAS transcription factors that suppress GA signaling [25].

Plant age promotes flowering via another miRNA route, namely miR319. The expression of miR319 at the SAM increases as the seedling ages, and directly targets LANCEOLATE $(L A)$, a tomato TCP4 homolog [25,33]. LA is a regulator of GA responses [34] and therefore 
the age-dependent flowering pathway appears to function via a complex network that regulates meristem maturity by fine-tuning GA concentrations [25].

Genetic experiments with varying allelic combinations of $s p$ and $s f t$ have led to the suggestion that the meristematic fates (i.e., termination or continuation of growth) depend on the SFT / SP ratio. Moreover, primary and sympodial meristems differ in their sensitivity to similar SFT / SP ratios [35-37]. Therefore, altering the ratio of flowering-promoting and growth-promoting alleles of CETS genes could offer a means for shaping plant architecture in specific ways. This was recently demonstrated by [38], who produced a continuum of tomato plant architectures by targeting the wild S. pimpinellifolium SP and SP5G orthologs to CRISPR-Cas9 genome editing.

Another feasible target for genome editing would be the gene lateral suppressor (ls), a member of the GRAS-domain transcription factor family, whose loss-of-function mutation results in a nearly complete lack of axillary shoot outgrowth [39]. As the removal of axillary shoots (suckers) is a costly operation in the tomato industry, the $l s$ mutation would have agronomic value. However, $l s$ mutation has serious pleiotropic effects on fertility, which limits its direct use in breeding. Engineering $l s$ by genome editing to alter its expression pattern selectively in AXMs could be a way to produce non-suckering tomato cultivars without the deleterious effects of fruit yield [40].

\subsection{Apple}

Rosaceous fruit trees include the genera Malus (apples), Pyrus (pears) and Prunus (peach, cherry, etc.) [41] and consist of deciduous, polycarpic species with a diversity of growth patterns that differ even within a genus. For example, cherries (Prunus avium), almonds (P. amygdalus) and peaches (P. persica) have strictly monopodial branching patterns throughout their life span, whereas apricots (P. armeniaca) follow a sympodial growth pattern caused by the frequent spontaneous abortion of the SAM at growth cessation [42]. Due to the diverse growth patterns, we focus this review on the apple (Malus domestica Borkh.), for which the molecular mechanisms regulating tree architecture have started to emerge during the recent years.

The overall shape of the tree is determined during the juvenile period, which lasts several years [43] and depends on two main factors: the fate of axillary buds and the position of the AXB on the parent branch [42,44]. Axillary buds can be dormant, develop vegetative shoots or bear reproductive organs. In the apple, vegetative shoots are often referred to as long shoots with vigorous vegetative growth. Short shoots (spurs) develop typically from AXBs located within the middlemost two quarters of the length of the parental branch [42]. Short shoots are rosette-like structures with a few leaves accompanied by AXBs and limited extension growth, and they terminate in an inflorescence. The axis of the short shoot is called a bourse, and it can go on to develop new short shoots in a sympodial fashion from its axillary buds in the following seasons $[45,46]$.

Vegetative shoots are classified based on the age and position of the bud from which they sprout. Sylleptic, or immediate, shoots emerge from buds developed during the same season. Proleptic, or delayed, shoots grow from buds developed in the previous season; and epicormic shoots (also known as suckers or water shoots) sprout from buds that have been dormant for a longer period, arising directly from the trunk or from an old branch [47,48].

During the juvenile period, there is a vigorous growth expansion from spring through summer and, as the tree matures, floral initiation occurs while day length shortens, before the temperature drop triggers winter dormancy. Once the dormancy period concludes, both vegetative and flowering buds burst, expanding the canopy while flowering and fructifying during spring and summer. When an inflorescence emerges at the shoot apex, vegetative growth continues from the bud directly beneath the SAM, continuing vegetative growth in a sympodial pattern [45,49-51].

Since proleptic shoots are regarded as more productive [52,53], traditional culture techniques commonly include pruning sylleptic shoots. Rosaceae fruit trees were domesticated as early as during the Neolithic and therefore many training methods have been developed 
to maximize fruit size, sun exposure, aeration, or to ease harvesting among other factors. Traditional cultivars and rootstocks were tall trees with a lifespan up to several hundred years in some cases, which favored low plantation densities and training methods that emphasized flat growth, such as espaliers, vases, etc. Modern dwarfing rootstocks lead to a sharp increase in plantation densities and favor vertical growth with limited vigor. In modern planting schemes, the most vigorous branches are pruned periodically [54].

Dwarfing rootstocks not only limit the vigor of the tree as a whole, but also are able to alter the phenotype of the scion in multiple ways. Dwarfing rootstocks may shorten internodes of the scion, limit the vegetative growth period, enhance the proportion of floral buds and widen the angles between the axillary shoots and the main trunk. These factors interact with each other. For example, a shorter period of vegetative expansion means a smaller number of buds competing for resources, increasing the viability and quality of the flower buds. Moreover, more flower buds (and fruits) per length of branch enhance bending and flattens the branches, which limits vegetative expansion [55].

Some studies showed that dwarfing rootstocks have a reduced diameter and density of xylem vessels, which reduces water flow to the scion and photosynthesis efficiency [56]. A low auxin/cytokinin ratio might explain the abnormal xylem development [57] and in fact, auxin transport to the roots is reduced in dwarfing rootstocks [58]. In line with that, the auxin transport genes $M d P I N 1 b$ and $M d P I N 8 a$ show lower expression levels in scions grafted in dwarfing rootstocks. Furthermore, the expression of the auxin biosynthetic gene MdYUCCA10a is also lower in scions grafted into dwarfing rootstocks [59], which may imbalance the auxin/cytokinin ratio.

Auxin deficiency reduces root mass $[60,61]$, hampering cytokinin synthesis in the roots. This, combined with the diminished xylem transport capacity, could lower cytokinin availability. Scions grafted on dwarfing rootstocks have lower cytokinin concentrations, which is likely related to the low expression levels of the cytokinin biosynthesis gene MdIPT5b [56,58,62]. Abscisic acid (ABA) is also produced in the roots and transported to the aerial part. Various authors have hypothesized that the restricted water flow increases the concentrations of ABA in the scion, explaining the higher concentrations associated with dwarfing phenotypes. In addition, high ABA concentrations correlate with a reduced root mass $[63,64]$.

Gibberellic acid (GA) is known to regulate internode length [65] and growth regulator treatments have been effective in shortening the internode length. However, dwarfing rootstocks do not reduce internode length, but rather reduce the number of nodes by shortening the growing period. This means that low GA levels or GA insensitivity are not the only factor resulting in dwarfing phenotypes [55]. Furthermore, transgenic apple scions with the silenced GA biosynthesis gene MdGA20ox1 remain short despite of being grafted into invigorating rootstocks, revealing that the dwarfing phenotype is independent from the GA transported from the rootstock [66]. That being said, dwarfing rootstocks lower the GA concentrations in the scion [67]. In addition, the genes homologous to the GA deactivator GA2ox, DkGA2ox1 and PslGA2ox, are related to dwarfing phenotypes in the persimmon and plum, respectively $[68,69]$. Quantitative trait loci analysis has revealed that the dwarfing phenotype is controlled by three loci. However, the genes behind those loci remain unknown $[45,70,71]$. Fine mapping may reveal this information in the future.

The dwarfing phenotype results from multiple interactions and thus the exact breeding targets are not clear. On the other hand, precocity and a shortened growth season may be major factors defining tree architecture and therefore should be of main interest for breeding programs. Another architecture phenotype worth of interest was discovered in the apple cultivar 'McIntosh'. Originated from a bud mutation, the cultivar was named 'Mcintosh Wijcik'. These trees have a main trunk with short internodes, almost no branches, and numerous fruit-bearing spurs. Thus, it does not require pruning, can be planted in extremely high densities and it might even allow mechanizing the harvest process [72]. The phenotype is caused by an insertion of a Gypsy-like retrotransposon associated with the locus harboring the dominant Columnar (Co) mutation [73]. The retrotransposon insertion 
does not disrupt any obvious coding regions [73], but it causes a change in the expression pattern of a gene located $16 \mathrm{~kb}$ downstream of the insertion. This gene was identified as a Malus homolog of a gene encoding a 2-oxoglutarate dioxygenase (MdDOX-Co, [74-76]), and it is expressed in the roots of wild-type trees. In contrast, columnar trees show MdDOXCo transcription also in the aerial part [77]. GA3 application restores the phenotype partially, suggesting that MdDOX-Co causes GA deficiency [78]. Furthermore, it has been recently shown that MdDOX-Co deflects substrates essential for GA 3-oxidases, hijacking GA synthesis [79]. On the other hand, [55] did not report columnar phenotypes on wild-type apple trees treated with GA inhibitors, meaning that MdDOX-Co may have additional effects apart from the disruption of GA metabolism. The columnar phenotype expands on the advantages of dwarfing rootstocks and can be incorporated with relative ease into apple breeding programs because it is dominantly inherited. Further research is needed to understand the functions of MdDOX-Co in apple and other Rosaceous fruit trees.

\subsection{Strawberry}

The cultivated strawberry (Fragaria $\times$ ananassa) and one of its wild diploid progenitors, the woodland strawberry (Fragaria vesca L.), are herbaceous perennials. In both species, the vegetative primary shoot apical meristem produces leaf initials, each accompanied by an axillary meristem at the leaf base. The strawberry main stem (or crown) grows as a rosette, consisting of very short internodes. When induced to flower, the SAM forms a terminal inflorescence and vegetative growth continues in sympodial fashion from the youngest AXM located directly below the induced SAM (Figure 3A). The older AXMs form $\mathrm{AXBs}$, which can either remain dormant or develop into stolons (runners) or branch crowns (BCs), depending on endogenous and environmental signals. Strawberry runners have long internodes and vigorous vegetative growth, whereas BCs have very short internodes and, similarly to the main crown, can form terminal inflorescences under favorable environmental conditions [80-82].
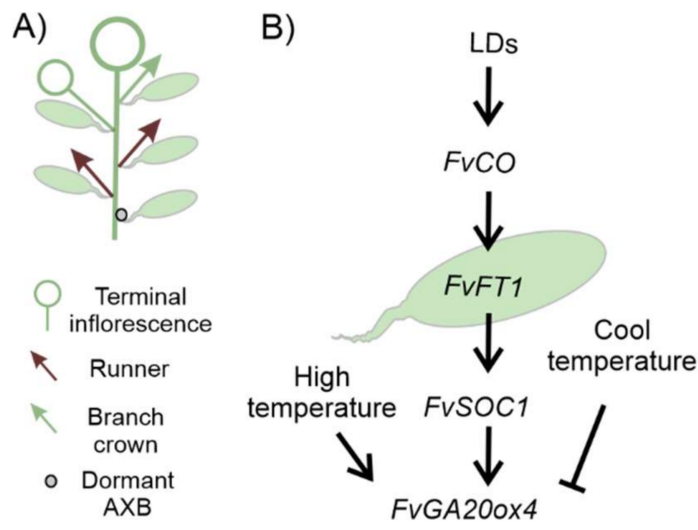

Figure 3. Strawberry growth habit and regulation of GA20ox4 expression. (A) Strawberry main crown; each leaf is accompanied by an axillary bud (AXB), which may remain dormant or develop into a runner or a branch crown. The uppermost branch crown below a terminal inflorescence continues plant growth in a sympodial fashion. Older branch crowns can bear their own terminal inflorescences. Each branch crown produces leaves and accompanying AXBs not shown in the figure. (B) Longs days (LDs) upregulate the genetic pathway leading to the upregulation of FvGA20ox4 in AXBs and resulting in runner development.

The environmental responses in terms of $\mathrm{AXB}$ fate are similar in both woodland strawberry and cultivated strawberry. Floral induction at the primary SAM forces the uppermost AXM to form a branch crown to continue producing plant structures as the new main axis of growth $[81,82]$. The fates of the other AXBs show more plastic responses, with long day (LD) conditions and warm temperature promoting runner development. Short days (SDs) and cool temperature, on the other hand, promote the development of 
BCs [82]. The exact day lengths and temperatures that promote one fate or the other depend heavily on the genotype, and also the day length $\times$ temperature interaction has a strong influence on AXB fate [83-85]. Moreover, certain genotypes have an altered day length requirement both for floral induction and for $\mathrm{AXB}$ fate determination. These genotypes are often referred to as "perpetual flowering" to distinguish them from the typical seasonal flowering genotypes. However, the majority of perpetual flowering genotypes are actually quantitative LD plants [82,86,87].

The balance of strawberry $\mathrm{AXB}$ fates, i.e., vegetative runner versus potentially generative $\mathrm{BC}$, has consequences on strawberry production. The cultivated strawberry is propagated clonally via runners, and therefore scarce runnering capacity leads to difficulties in propagation. On the other hand, the apical meristems on BCs can be florally induced and thus an adequate number of BCs secures a good yield. Runnering capacity in perpetual flowering strawberry genotypes is often too low, diminishing the utility of these genotypes in practical cultivation. Improving the balance between runnering and BC development in perpetual flowering genotypes would therefore benefit the strawberry industry.

Knowledge on the genetic pathways regulating the AXB fate in strawberry has started to emerge recently. A study taking advantage of a runnerless woodland strawberry mutant suggested that a functional F. vesca homolog of a gene encoding gibberellin 20-oxidase 4 (FvGA20ox4) is necessary for runner development [88], and this finding was later confirmed by [82] by silencing the native FvGA200x4 by RNAi. Moreover, [82] demonstrated that FvGA20ox4 is transcriptionally regulated by environmental conditions; in the perpetual flowering genotype FvGA20ox 4 was upregulated by SDs at $24^{\circ} \mathrm{C}$, while in seasonal flowering genotypes upregulation took place exclusively under LD conditions. FvGA20ox4 exerts its function via the GA-GID1-DELLA pathway [89], which is a hormonal signaling pathway conserved in both dicots and monocots [90].

A series of reports show that the photoperiod regulates FvGA20ox4 transcription via the pathway, including the F. vesca homologs of CONSTANS (FvCO, [91]), FLOWERING LOCUS T (FvFT1, [92,93]), and SUPPRESSOR OF OVEREXPRESSION OF CONSTANS1 (FvSOC1, [94]). This pathway is active and upregulates FvGA20ox4 specifically under LD conditions at temperatures between 16 to $18{ }^{\circ} \mathrm{C}$ (Figure 3B). The genes involved in the regulation of FvGA20ox4 at temperatures higher or lower than $16-18^{\circ} \mathrm{C}$ remain less well characterized. At the lower temperatures of $10-11^{\circ} \mathrm{C}$, FvGA20ox4 is repressed, and runner development inhibited independently of FvSOC1 with a concomitant increase in the frequency of AXBs developing into branch crowns. At the higher temperatures of $22-23{ }^{\circ} \mathrm{C}$, unknown factor(s) upregulate FvGA20ox4 and promote runner development [82].

The recent advances in elucidating the runnering/BC formation balance in strawberries pave the way for the genetic improvement in the cultivated strawberry. Genetic studies have demonstrated that changes in promoter elements of key genes can have drastic consequences on the plant developmental program [95], and therefore gaining knowledge on potential key genes is of paramount importance for cultivar improvement. Key genes can be used as breeding targets, either by the means of traditional breeding or by genomic editing, whose use in strawberries has been described [96]. Understanding the genetic regulation of $\mathrm{AXB}$ fate in strawberries may be useful also for breeders of other Rosaceaous crops, especially in tree species.

\subsection{Citrus}

Cultivated species within the genus Citrus (Rutaceae family) include sweet and sour oranges, lemons, limes, mandarins, grapefruits and other less commonly consumed fruits [97]. The most commonly cultivated species of Citrus are long-lived perennial trees with a juvenile period of six or more years. During the domestication of Citrus, the selected traits have predominantly been related to fruit quality aspects [98], while traits related to tree architecture have received less attention. Citrus species have traditionally been grown at the wide spacing between plants; for example, the typical planting density in new orange orchards in Florida was 139 trees per acre (344 trees per hectare) at the end of the 1980s [99]. Due to the 
rising demand for mechanical harvesting and improving land use efficiency, high-density planting schemes have been evaluated and adopted. These planting schemes typically have an excess of 800 trees per acre (approximately 2000 trees per hectare) and require manual pruning to avoid crowding [100]. Some of the issues related to vigorous vegetative growth can be overcome by the selection of a dwarfing rootstock, although in some cases this may lead to incompatibility problems between the scion and the rootstock [101].

The long juvenile period, high heterozygosity, as well as issues with pollen and ovule sterility have severely hampered Citrus breeding. Moreover, Citrus has unique reproductive biology, in which apomixis (the development of seeds without fertilization) and embryony complicate the production of hybrids. For these reasons, the majority of presently used scion and rootstock cultivars are chance seedlings or bud sports [101].

The breeding of Citrus could greatly benefit from the adoption of recently developed molecular precision methods for genome editing. The efficacy of the CRISPR/Cas9 genome editing system has already been demonstrated in several Citrus species, including sweet orange (C. sinensis "Valencia", [102]), the commonly used rootstock cultivar Carrizo citrange (C. sinensis "Washington" sweet orange $\times$ Poncirus trifoliata, [103]), and Duncan grapefruit (C. maxima $\times$ C. sinensis, [104]). The mentioned studies were either proof-of-concept experiments demonstrating the feasibility of using CRISPR genome editing in Citrus ([102,103]), or targeted the promoter of a disease susceptibility-related gene [104].

Recently, the CRISPR genome editing technology has been utilized to alter and study tree architectural traits in Citrus. Young leaf axils in juvenile trees of Citrus species typically have a dormant axillary meristem and a thorn meristem (Figure 4A). Both show meristematic activity as demonstrated by the presence of transcripts of the Citrus orthologs of SHOOT MERISTEMLESS (CSSTM) and WUSCHEL (CsWUS) [105]. While the expression of CSSTM and CsWUS persists in dormant axillary meristems, their expression is repressed in the actively growing, terminating thorns. By using comparative transcriptomics, the authors were able to show that the maintenance of meristematic activity in developing thorns depends on THORN IDENTITY (TI1) and THORN IDENTITY2 (TI2), two homologs of the BRANCHED1 gene of Arabidopsis and the TB1 of maize. By mutating both homologs, [105] were able to show that the genes are negative regulators of CsWUS and stem cell activity. The disruption of TI1 and TI2 activity led to the development of axillary branches instead of thorns and enhanced the outgrowth of the actual axillary meristems, resulting in a very bushy plant architecture [105].

In a follow-up study, [106] elucidated the molecular mechanism that ensures the sustainment of meristematic activity in Citrus AXMs. The authors compared the transcriptomes of thorned and thornless key lime (C. aurantifolia) cultivars; in the thorned cultivar, the thorn primordia terminate in a sharp tip and the neighboring AXM remains dormant as is typical in Citrus, while in the thornless cultivar the thorn meristem is transformed into a second dormant AXM. Transcriptome analysis of these two types of cultivars revealed that a gene homologous to TFL1 and CEN1 (termed CsCEN1) was upregulated in the meristem tissues of the thornless cultivar. Disrupting CsCEN1 function using CRISPR/Cas9 genome editing resulted in plants with a dramatic change in phenotype, with every AXM growing out as a determinate thorn. The overexpression of CsCEN1 converted the thorn primordia into dormant AXMs, or even into small branches. The authors of [106] further demonstrated that TI1 and TI2 are epistatic to CsCEN1, and that CsCEN1 represses TI1 in dormant AXMs, thus maintaining indeterminate growth (Figure 4B).

The above-mentioned studies demonstrate the feasibility of modifying tree architecture by targeting a limited number of genes in yet another species, the Citrus. Improving tree architectural traits can thus be achieved either by identifying natural variations within a set of tree architecture-related genes, or by introducing a new variation using genome editing. Improvements in tree architecture will enable the use of high-density planting schemes, perhaps in combination with mechanical harvesting, to further decrease cultivation costs and increase the yield per hectare in Citrus. 


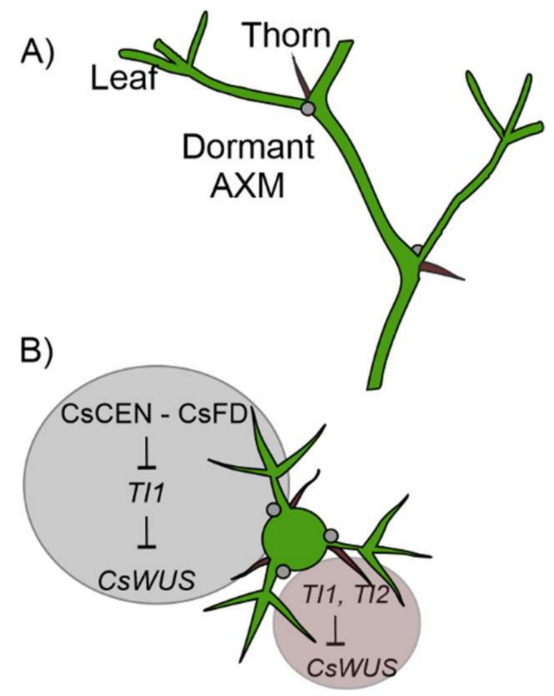

Figure 4. Regulation of plant architecture in Citrus. (A) Citrus growth habit showing two leaves accompanied by a thorn and a dormant axillary meristem (AXM) at the leaf axil. (B) Genetic network regulating AXM fate in Citrus. AXMs loose CsWUS activity and develop into determinate thorns when TI1 and TI2 repress CsWUS in thorn meristems. AXMs remain in an undifferentiated, dormant state when the protein complex formed by CsCEN and CsFD represses TI1, resulting in CsWUS activity and maintenance of stem cell proliferation. Dormant AXBs are depicted by filled gray circles. The figure summarizes findings presented in $[105,106]$.

\section{Concluding Remarks}

In this review, we attempted to provide examples of the genetic mechanisms that regulate $\mathrm{AXB}$ fate in different crops. This is by no means an extensive account of $\mathrm{AXB}$ fate regulation in plants, but rather serves as a starting point for an interested reader. The key message arising from the selected example plant species is that the genetic mechanisms regulating AXB fate do not necessarily entail a large number of genes. Actually, a limited number of major effect genes appears to regulate plant form, and changing the expression patterns or functions of these genes have drastic effects on plant architecture. From the point of view of plant breeding, this is excellent news. The identification of major-effect genes will provide plant breeders with specific breeding targets, thus increasing the accuracy and feasibility of breeding programs.

Author Contributions: Conceptualization and preparation of the original draft, J.A. and E.K. All authors have read and agreed to the published version of the manuscript.

Funding: J.A. was funded by the Doctoral Program of Plant Sciences (University of Helsinki, Finland). E.K. was funded from an Academy of Finland grant (grant number 317306) awarded to Timo Hytönen, the Principal Investigator of the strawberry group.

Institutional Review Board Statement: Not applicable.

Informed Consent Statement: Not applicable.

Conflicts of Interest: The authors declare no conflict of interest. The funders had no role in the writing of the manuscript.

\section{References}

1. Khush, G.S. Green revolution: The way forward. Nat. Rev. 2001, 2, 815-822. [CrossRef] [PubMed]

2. Vernoux, T.; Besnard, F.; Godin, C. What shoots can teach about theories of plant form. Nat. Plants 2021, 7, 716-724. [CrossRef] [PubMed]

3. Wang, Y.; Jiao, Y. Axillary meristem initiation-A way to branch out. Curr. Opin. Plant Biol. 2018, 41, 61-66. [CrossRef] [PubMed]

4. Leyser, O. The control of shoot branching: An example of plant information processing. Plant Cell Environ. 2009, 32, 694-703. [CrossRef] [PubMed] 
5. Iltis, H.H. From teosinte to maize: The catastrophic sexual transmutation. Science 1983, 222, 886-894. [CrossRef]

6. Doebley, J.; Stec, A.; Hubbard, L. The evolution of apical dominance in maize. Nature 1997, 386, 485-488. [CrossRef]

7. Doebley, J.; Stec, A. Genetic analysis of the morphological differences between maize and teosinte. Genetic 1991, 129, 285-295. [CrossRef]

8. Doebley, J.S.; Stec, A.; Gustus, C. Teosinte branched1 and the origin of maize: Evidence for epistasis and the evolution of dominance. Genetics 1995, 141, 333-346. [CrossRef]

9. Burnham, C. Teosinte branched. Maize Genet. Coop. News Lett. 1959, 33, 74.

10. Hubbard, L.; McSteen, P.; Doebley, J.; Hake, S. Expression patterns and mutant phenotype of teosinte branched1 correlate with growth suppression in maize and teosinte. Genetics 2002, 162, 1927-1935. [CrossRef]

11. Cubas, P.; Lauter, N.; Doebley, J.; Coen, E. The TCP domain: A motif found in proteins regulating plant growth and development. Plant J. 1999, 18, 215-222. [CrossRef] [PubMed]

12. Clark, R.M.; Wagler, T.N.; Quijada, P.; Doebley, J. A distant upstream enhancer at the maize domestication gene tb1 has pleiotropic effects on plant and inflorescent architecture. Nat. Genet. 2006, 38, 594-597. [CrossRef] [PubMed]

13. Zhou, L.; Zhang, J.; Yan, J.; Song, R. Two transposable element insertions are causative mutations for the major domestication gene teosinte branched 1 in modern maize. Cell Res. 2011, 21, 1267-1270. [CrossRef] [PubMed]

14. Sheridan, W.F. Maize developmental genetics: Genes of morphogenesis. Annu. Rev. Genet. 1988, 22, 353-385. [CrossRef] [PubMed]

15. Shaver, D.L. Perennial Maize. J. Hered. 1967, 58, 271-273. [CrossRef]

16. Whipple, C.J.; Kebrom, T.H.; Weber, A.L.; Yang, F.; Hall, D.; Meeley, R.; Schmidt, R.; Doebley, J.; Brutnell, T.P.; Jackson, D.P. grassy tillers1 promotes apical dominance in maize and responds to shade signals in the grasses. Proc. Natl. Acad. Sci. USA 2011, 108, E506-E512. [CrossRef]

17. Kebrom, T.H.; Burson, B.L.; Finlayson, S.A. Phytochrome B Represses Teosinte Branched1 Expression and Induces Sorghum Axillary Bud Outgrowth in Response to Light Signals. Plant Physiol. 2006, 140, 1109-1117. [CrossRef]

18. Dong, Z.; Xiao, Y.; Govindarajulu, R.; Feil, R.; Siddoway, M.L.; Nielsen, T.; Lunn, J.E.; Hawkins, J.; Whipple, C.; Chuck, G. The regulatory landscape of a core maize domestication module controlling bud dormancy and growth repression. Nat. Commun. 2019, 10, 3810. [CrossRef]

19. Dong, Z.; Li, W.; Unger-Wallace, E.; Yang, J.; Vollbrecht, E.; Chuck, G. Ideal crop plant architecture is mediated by tassels replace upper ears1, a BTB/POZ ankyrin repeat gene directly targeted by TEOSINTE BRANCHED1. Proc. Natl. Acad. Sci. USA 2017, 114, E8656-E8664. [CrossRef]

20. Studer, A.J.; Wang, H.; Doebley, J.F. Selection During Maize Domestication Targeted a Gene Network Controlling Plant and Inflorescence Architecture. Genetic 2017, 207, 755-765. [CrossRef]

21. Svitashev, S.; Schwartz, C.; Lenderts, B.; Young, J.K.; Cigan, A.M. Genome editing in maize directed by CRISPR-Cas9 ribonucleoprotein complexes. Nat. Commun. 2016, 7, 13274. [CrossRef]

22. Lifschitz, E.; Eshed, Y. Universal florigenic signals triggered by FT homologues regulate growth and flowering cycles in perennial day-neutral tomato. J. Exp. Bot. 2006, 57, 3405-3414. [CrossRef]

23. Sawhney, V.K.; Greyson, R.I. On the initiation of the inflorescence and floral organs in tomato (Lycopersicon esculentum). Can. J. Bot. 1972, 50, 1493-1495. [CrossRef]

24. Yeager, A.F. Determinate growth in the tomato. J. Hered. 1927, 18, 263-265. [CrossRef]

25. Silva, G.F.F.; Silva, E.M.; Correa, J.P.O.; Vicente, M.H.; Jiang, N.; Notini, M.M.; Junior, A.C.; De Jesus, F.A.; Castilho, P.; Carrera, E.; et al. Tomato floral induction and flower development are orchestrated by the interplay between gibberellin and two unrelated microRNA-controlled modules. New Phytol. 2019, 221, 1328-1344. [CrossRef] [PubMed]

26. Pnueli, L.; Carmel-Goren, L.; Hareven, D.; Gutfinger, T.; Alvarez, J.; Ganal, M.; Zamir, D.; Lifschitz, E. The SELF-PRUNING gene of tomato regulates vegetative to reproductive switching of sympodial meristems and is the ortholog of CEN and TFL1. Development 1998, 125, 1979-1989. [CrossRef]

27. Thouet, J.; Quinet, M.; Ormenese, S.; Kinet, J.M.; Périlleux, C. Revisiting the involvement of SELF-PRUNING in the sympodial growth of tomato. Plant Physiol. 2008, 148, 61-64. [CrossRef]

28. Molinero-Rosales, N.; Latorre, A.; Jamilena, M.; Lozano, R. SINGLE FLOWER TRUSS regulates the transition and maintenance of flowering in tomato. Planta 2004, 218, 427-434. [CrossRef]

29. Lifschitz, E.; Ayre, B.G.; Eshed, Y. Florigen and anti-florigen-A systemic mechanism for coordinating growth and termination in flowering plants. Front. Plant Sci. 2014, 5, 465. [CrossRef]

30. Pnueli, L.; Gutfinger, T.; Hareven, D.; Ben-Naim, O.; Ron, N.; Adir, N.; Lifschitz, E. Tomato SP-Interacting Proteins Define a Conserved Signaling System That Regulates Shoot Architecture and Flowering. Plant Cell 2001, 13, 2687. [CrossRef]

31. Soyk, S.; Müller, N.A.; Park, S.J.; Schmalenbach, I.; Jiang, K.; Hayama, R.; Zhang, L.; van Eck, J.; Jiménez-Gómez, J.M.; Lippman, Z.B. Variation in the flowering gene SELF PRUNING 5G promotes day-neutrality and early yield in tomato. Nat. Genet. 2016, 49, 162-168. [CrossRef]

32. Song, J.; Zhang, S.; Wang, X.; Sun, S.; Liu, Z.; Wang, K.; Wan, H.; Zhou, G.; Li, R.; Yu, H.; et al. Variations in Both FTL1 and SP5G, Two Tomato FT Paralogs, Control Day-Neutral Flowering. Mol. Plant 2020, 13, 939-942. [CrossRef] [PubMed]

33. Parapunova, V.; Busscher, M.; Busscher-Lange, J.; Lammers, M.; Karlova, R.; Bovy, A.G.; Angenent, G.C.; de Maagd, R.A. Identification, cloning and characterization of the tomato TCP transcription factor family. BMC Plant Biol. 2014, 14, 157. [CrossRef] [PubMed] 
34. Yanai, O.; Shani, E.; Russ, D.; Ori, N. Gibberellin partly mediates LANCEOLATE activity in tomato. Plant J. 2011, 68, 571-582. [CrossRef] [PubMed]

35. Shalit, A.; Rozman, A.; Goldshmidt, A.; Alvarez, J.P.; Bowman, J.L.; Eshed, Y.; Lifschitz, E. The flowering hormone florigen functions as a general systemic regulator of growth and termination. Proc. Natl. Acad. Sci. USA 2009, 106, 8392-8397. [CrossRef]

36. Krieger, U.; Lippman, Z.B.; Zamir, D. The flowering gene SINGLE FLOWER TRUSS drives heterosis for yield in tomato. Nat. Genet. 2010, 42, 459-463. [CrossRef] [PubMed]

37. Jiang, K.; Liberatore, K.; Park, S.J.; Alvarez, J.P.; Lippman, Z.B. Tomato Yield Heterosis Is Triggered by a Dosage Sensitivity of the Florigen Pathway That Fine-Tunes Shoot Architecture. PLoS Genet. 2013, 9, e1004043. [CrossRef] [PubMed]

38. Li, T.; Yang, X.; Yu, Y.; Si, X.; Zhai, X.; Zhang, H.; Dong, W.; Gao, C.; Xu, C. Domestication of wild tomato is accelerated by genome editing. Nat. Biotechnol. 2018, 36, 1160-1163. [CrossRef]

39. Groot, S.P.; Keizer, L.C.; de Ruiter, W.; Dons, J.J. Seed and fruit set of the lateral suppressor mutant of tomato. Sci. Hortic. 1994, 59, 157-162. [CrossRef]

40. Zsögön, A.; Cermak, T.; Voytas, D.; Peres, L.E.P. Genome editing as a tool to achieve the crop ideotype and de novo domestication of wild relatives: Case study in tomato. Plant Sci. 2017, 256, 120-130. [CrossRef]

41. Potter, D.; Eriksson, T.; Evans, R.C.; Oh, S.; Smedmark, J.; Morgan, D.R.; Kerr, M.; Robertson, K.R.; Arsenault, M.; Dickinson, T.A.; et al. Phylogeny and classification of Rosaceae. Oesterreichische Bot. Z. 2007, 266, 5-43. [CrossRef]

42. Costes, E.; Crespel, L.; Denoyes, B.; Morel, P.; Demene, M.-N.; Lauri, P.-É. Bud structure, position and fate generate various branching patterns along shoots of closely related Rosaceae species: A review. Front. Plant Sci. 2014, 5, 666. [CrossRef] [PubMed]

43. Costes, E.; Guedon, Y. Modelling branching patterns on 1-year-old trunks of six apple cultivars. Ann. Bot. 2002, 89, 513-524 [CrossRef]

44. Kervella, J.; Pagès, L.; Génard, M. Growth Context and Fate of Axillary Meristems of Young Peach Trees. Influence of Parent Shoot Growth Characteristics and of Emergence Date. Ann. Bot. 1995, 76, 559-567. [CrossRef]

45. Foster, T.; Johnston, R.; Seleznyova, A. A Morphological and Quantitative Characterization of Early Floral Development in Apple (Malus $x$ domestica Borkh.). Ann. Bot. 2003, 92, 199-206. [CrossRef] [PubMed]

46. Wilkie, J.D.; Sedgley, M.; Olesen, T. Regulation of floral initiation in horticultural trees. J. Exp. Bot. 2008, 59, 3215-3228. [CrossRef]

47. Barthélémy, D.; Caraglio, Y. Plant Architecture: A Dynamic, Multilevel and Comprehensive Approach to Plant Form, Structure and Ontogeny. Ann. Bot. 2007, 99, 375-407. [CrossRef]

48. DeJong, T.; Negron, C.; Favreau, R.; Day, K.; Costes, E.; Lopez, G.; Guedon, Y. Using concepts of shoot growth and architecture to understand and predict responses of peach trees to pruning. Acta Hortic. 2012, 962, 225-232. [CrossRef]

49. Costes, E.; Guédon, Y. Deciphering the ontogeny of a sympodial tree. Trees 2011, 26, 865-879. [CrossRef]

50. Fortanier, E.J.; Jonkers, H. Juvenility and maturity of plants as influenced by their ontogenetical and physiological ageing. Acta Hortic. 1976, 56, 37-44. [CrossRef]

51. Segura, V.; Cilas, C.; Costes, E. Dissecting apple tree architecture into genetic, ontogenetic and environmental effects mixed linear model. New Phytol. 2008, 178, 302-314. [CrossRef]

52. Fyhrie, K.; Llinàs, M.T.P.; López, G.; DeJong, T. How does peach fruit set on sylleptic shoots borne on epicormics compare with fruit set on proleptic shoots? Eur. J. Hortic. Sci. 2018, 83, 3-11. [CrossRef]

53. Prats-Llinàs, M.T.; López, G.; Fyhrie, K.; Pallas, B.; Guédon, Y.; Costes, E.; DeJong, T.M. Long proleptic and sylleptic shoots in peach (Prunus persica L. Batsch) trees have similar, predetermined, maximum numbers of nodes and bud fate patterns. Ann. Bot. 2019, 123, 993-1004. [CrossRef] [PubMed]

54. Cornille, A.; Antolín, F.; Garcia, E.; Vernesi, C.; Fietta, A.; Brinkkemper, O.; Kirleis, W.; Schlumbaum, A.; Roldán-Ruiz, I. A Multifaceted Overview of Apple Tree Domestication. Trends Plant Sci. 2019, 24, 770-782. [CrossRef] [PubMed]

55. Webster, A. Vigour mechanisms in dwarfing rootstocks for temperate FRUIT trees. Acta Hortic. 2004, 658, 29-41. [CrossRef]

56. Zhou, Y.; Tian, X.; Yao, J.; Zhang, Z.; Wang, Y.; Zhang, X.; Li, W.; Wu, T.; Han, Z.; Xu, X.; et al. Morphological and photosynthetic responses differ among eight apple scion-rootstock combinations. Sci. Hortic. 2020, 261, 108981. [CrossRef]

57. Roberts, L.W. The initiation of Xylem differentiation. Bot. Rev. 1969, 35, 201-250. [CrossRef]

58. Saeed, M.; Dodd, P.B.; Sohail, L. Anatomical studies of stems, roots and leaves of selected citrus rootstock varieties in relation to their varieties in relation to their vigour. J. Hortic. For. 2010, 2, 87-94.

59. Song, C.; Zhang, D.; Zhang, J.; Zheng, L.; Zhao, C.; Ma, J.; An, N.; Han, M. Expression analysis of key auxin synthesis, transport, and metabolism genes in different young dwarfing apple trees. Acta Physiol. Plant. 2016, 38, 43. [CrossRef]

60. Kamboj, J.S.; Browning, G.; Quinlan, J.D.; Blake, P.S.; Baker, D.A. Polar transport of [3H]-IAA in apical shoot segments of different apple rootstocks. J. Hortic. Sci. 1997, 72, 773-780. [CrossRef]

61. Li, H.L.; Zhang, H.; Yu, C.; Ma, L.; Wang, Y.; Zhang, X.Z.; Han, Z.H. Possible roles of auxin and zeatin for initiating the dwarfing effect of M9 used as apple rootstock or interstock. Acta Physiol. Plant. 2011, 34, 235-244. [CrossRef]

62. Feng, Y.; Zhang, X.; Wu, T.; Xu, X.; Han, Z.; Wang, Y. Methylation effect on IPT5b gene expression determines cytokinin biosynthesis in apple rootstock. Biochem. Biophys. Res. Commun. 2017, 482, 604-609. [CrossRef] [PubMed]

63. Kamboj, J.S.; Quinlan, J.D. The apple rootstock and its influence on endogenous hormones. Acta Hortic. 1998, 463, 143-152. [CrossRef]

64. Tworkoski, T.; Fazio, G. Effects of Size-Controlling Apple Rootstocks on Growth, Abscisic Acid, and Hydraulic Conductivity of Scion of Different Vigor. Int. J. Fruit Sci. 2015, 15, 369-381. [CrossRef] 
65. McKim, S.M. Moving on up-Controlling internode growth. New Phytol. 2020, 226, 672-678. [CrossRef]

66. Bulley, S.M.; Wilson, F.M.; Hedden, P.; Phillips, A.L.; Croker, S.J.; James, D.J. Modification of gibberellin biosynthesis in the grafted apple scion allows control of tree height independent of the rootstock. Plant Biotechnol. J. 2005, 3, 215-223. [CrossRef] [PubMed]

67. Van Hooijdonk, B.; Woolley, D.; Warrington, I.; Tustin, S. Rootstocks Modify Scion Architecture, Endogenous Hormones, and Root Growth of Newly Grafted 'Royal Gala' Apple. J. Am. Soc. Hortic. Sci. 2011, 136, 93-102. [CrossRef]

68. Dong, Y.; Ye, X.; Xiong, A.; Zhu, N.; Jiang, L.; Qu, S. The regulatory role of gibberellin related genes DKGA2ox1 and MIR171f_3 in persimmon dwarfism. Plant Sci. 2021, 310, 110958. [CrossRef]

69. El-Sharkawy, I.; El Kayal, W.; Prasath, D.; Fernández, H.; Bouzayen, M.; Svircev, A.M.; Jayasankar, S. Identification and genetic characterization of a gibberellin 2-oxidase gene that controls tree stature and reproductive growth in plum. J. Exp. Bot. 2011, 63, 1225-1239. [CrossRef]

70. Harrison, N.; Harrison, R.J.; Barber-Perez, N.; Cascant-Lopez, E.; Cobo-Medina, M.; Lipska, M.; Conde-Ruíz, R.; Brain, P.; Gregory, P.J.; Fernandez-Fernandez, F. A new three-locus model for rootstock-induced dwarfing in apple revealed by genetic mapping of root bark percentage. J. Exp. Bot. 2016, 67, 1871-1881. [CrossRef]

71. Pilcher, R.R.; Celton, J.M.; Gardiner, S.E.; Tustin, D.S. Genetic Markers Linked to the Dwarfing Trait of Apple Rootstock 'Malling 9'. J. Am. Soc. Hortic. Sci. 2008, 133, 100-106. [CrossRef]

72. Kelsey, D.F.; Brown, S.K. 'McIntosh Wijcik': A columnar mutation of 'McIntosh' Apple proving useful in physiology and breeding research. Fruit Var. J. 1992, 46, 83-87.

73. Otto, D.; Petersen, R.; Brauksiepe, B.; Braun, P.; Schmidt, E.R. The columnar mutation ("Co gene") of apple (Malus $\times$ domestica) is associated with an integration of a Gypsy-like retrotransposon. Mol. Breed. 2013, 33, 863-880. [CrossRef]

74. Okada, K.; Wada, M.; Moriya, S.; Katayose, Y.; Fujisawa, H.; Wu, J.; Kanamori, H.; Kurita, K.; Sasaki, H.; Fujii, H.; et al. Expression of a putative dioxygenase gene adjacent to an insertion mutation is involved in the short internodes of columnar apples (Malus $x$ domestica). J. Plant Res. 2016, 129, 1109-1126. [CrossRef] [PubMed]

75. Petersen, R.; Djozgic, H.; Rieger, B.; Rapp, S.; Schmidt, E.R. Columnar apple primary roots share some features of the columnarspecific gene expression profile of aerial plant parts as evidenced by RNA-Seq analysis. BMC Plant Biol. 2015, 15, 34. [CrossRef]

76. Wolters, P.J.; Schouten, H.J.; Velasco, R.; Si-Ammour, A.; Baldi, P. Evidence for regulation of columnar habit in apple by a putative 2OG-Fe(II) oxygenase. New Phytol. 2013, 200, 993-999. [CrossRef]

77. Wada, M.; Iwanami, H.; Moriya, S.; Hanada, T.; Moriya-Tanaka, Y.; Honda, C.; Shimizu, T.; Abe, K.; Okada, K. A root-localized gene in normal apples is ectopically expressed in aerial parts of columnar apples. Plant Growth Regul. 2018, 85, 389-398. [CrossRef]

78. Okada, K.; Wada, M.; Takebayashi, Y.; Kojima, M.; Sakakibara, H.; Nakayasu, M.; Mizutani, M.; Nakajima, M.; Moriya, S.; Shimizu, T.; et al. Columnar growth phenotype in apple results from gibberellin deficiency by ectopic expression of a dioxygenase gene. Tree Physiol. 2020, 40, 1205-1216. [CrossRef]

79. Watanabe, D.; Takahashi, I.; Jaroensanti-Tanaka, N.; Miyazaki, S.; Jiang, K.; Nakayasu, M.; Wada, M.; Asami, T.; Mizutani, M.; Okada, K.; et al. The apple gene responsible for columnar tree shape reduces the abundance of biologically active gibberellin. Plant J. 2021, 105, 1026-1034. [CrossRef]

80. Darrow, G.M. The Strawberry; Holt, Rinehart and Winston: New York, NY, USA, 1966.

81. Battey, N.H.; le Miere, P.; Tehranifar, A.; Cecik, C.; Taylor, S.; Shrives, K.; Hadley, P.; Greenland, A.; Darby, J.; Wilkinson, M. Genetic and environmental control of flowering in strawberry. In Genetic and Environmental Manipulation of Horticultural Crops; Cockshull, K.E., Gray, D., Seymour, G.B., Thomas, B., Eds.; CABI: Wallingford, UK, 1998; pp. 111-131.

82. Andrés, J.; Caruana, J.; Liang, J.; Samad, S.; Monfort, A.; Liu, Z.; Hytönen, T.; Koskela, E.A. Woodland strawberry axillary bud fate is dictated by a crosstalk of environmental and endogenous factors. Plant Physiol. 2021, 187, 1221-1234. [CrossRef]

83. Heide, O.M. Photoperiod and Temperature Interactions in Growth and Flowering of Strawberry. Physiol. Plant. 1977, 40, 21-26. [CrossRef]

84. Sønsteby, A. Short-day period and temperature interactions on growth and flowering of strawberry. Acta Hortic. 1997, 439, 609-616. [CrossRef]

85. Heide, O.M.; Sønsteby, A. Interactions of temperature and photoperiod in the control of flowering of latitudinal and altitudinal populations of wild strawberry (Fragaria vesca). Physiol. Plant. 2007, 130, 280-289. [CrossRef]

86. Sønsteby, A.; Heide, O.M. Long-day control of flowering in everbearing strawberries. J. Hortic. Sci. Biotechnol. 2007, 82, 875-884. [CrossRef]

87. Sønsteby, A.; Heide, O.M. Long-day rather than autonomous control of flowering in the diploid everbearing strawberry Fragaria vesca ssp. semperflorens. J. Hortic. Sci. Biotechnol. 2008, 83, 360-366. [CrossRef]

88. Tenreira, T.; Lange, M.J.P.; Lange, T.; Bres, C.; Labadie, M.; Monfort, A.; Hernould, M.; Rothan, C.; Denoyes, B. A Specific Gibberellin 20-Oxidase Dictates the Flowering-Runnering Decision in Diploid Strawberry. Plant Cell 2017, 29, 2168-2182. [CrossRef]

89. Caruana, J.C.; Sittmann, J.W.; Wang, W.; Liu, Z. Suppressor of Runnerless Encodes a DELLA Protein that Controls Runner Formation for Asexual Reproduction in Strawberry. Mol. Plant 2018, 11, 230-233. [CrossRef]

90. Sun, T.-P. The Molecular Mechanism and Evolution of the GA-GID1-DELLA Signaling Module in Plants. Curr. Biol. 2011, 21, R338-R345. [CrossRef]

91. Kurokura, T.; Samad, S.; Koskela, E.; Mouhu, K.; Hytönen, T. Fragaria vesca CONSTANS controls photoperiodic flowering and vegetative development. J. Exp. Bot. 2017, 68, 4839-4850. [CrossRef] 
92. Koskela, E.A.; Mouhu, K.; Albani, M.C.; Kurokura, T.; Rantanen, M.; Sargent, D.J.; Battey, N.H.; Coupland, G.; Elomaa, P.; Hytönen, T. Mutation inTERMINAL FLOWER1Reverses the Photoperiodic Requirement for Flowering in the Wild Strawberry Fragaria vesca. Plant Physiol. 2012, 159, 1043-1054. [CrossRef]

93. Rantanen, M.; Kurokura, T.; Jiang, P.; Mouhu, K.; Hytönen, T. Strawberry homologue of TERMINAL FLOWER1 integrates photoperiod and temperature signals to inhibit flowering. Plant J. 2015, 82, 163-173. [CrossRef] [PubMed]

94. Mouhu, K.; Kurokura, T.; Koskela, E.; Albert, V.A.; Elomaa, P.; Hytönen, T. The Fragaria vesca Homolog of SUPPRESSOR OF OVEREXPRESSION OF CONSTANS1 Represses Flowering and Promotes Vegetative Growth. Plant Cell 2013, 25, 3296-3310. [CrossRef] [PubMed]

95. Koskela, E.A.; Kurokura, T.; Toivainen, T.; Sønsteby, A.; Heide, O.M.; Sargent, D.J.; Isobe, S.; Jaakola, L.; Hilmarsson, H.; Elomaa, P.; et al. Altered regulation of TERMINAL FLOWER 1 causes the unique vernalisation response in an arctic woodland strawberry accession. New Phytol. 2017, 216, 841-853. [CrossRef]

96. Wilson, F.M.; Harrison, K.; Armitage, A.D.; Simkin, A.J.; Harrison, R.J. CRISPR/Cas9-mediated mutagenesis of phytoene desaturase in diploid and octoploid strawberry. Plant Methods 2019, 15, 45. [CrossRef] [PubMed]

97. Krueger, R.R.; Navarro, L. Citrus Germplasm Resources. In Citrus Genetics, Breeding and Biotechnology; Khan, I.A., Ed.; CAB International: Wallingford, Oxfordshire, UK, 2007; pp. 45-140.

98. Gonzalez-Ibeas, D.; Ibanez, V.; Perez-Roman, E.; Borredá, C.; Terol, J.; Talon, M. Shaping the biology of citrus: I. Genomic determinants of evolution. Plant Genome 2021, e20104. [CrossRef]

99. Wheaton, T.A.; Castle, W.S.; Whitney, J.D.; Tucker, D.P.H.; Muraro, R.P. A High density citrus planting. Proc. Fla. State Hortic. Soc. 1990, 103, 55-59.

100. Ladaniya, M.S.; Marathe, R.A.; Das, A.K.; Rao, C.N.; Huchche, A.D.; Shirgure, P.S.; Murkute, A.A. High density planting studies in acid lime (Citrus aurantifolia Swingle). Sci. Hortic. 2020, 261, 108935. [CrossRef]

101. Khan, I.A.; Kender, W.J. Citrus Breeding: Introduction and Objectives. In Citrus Genetics, Breeding and Biotechnology; Khan, I.A., Ed.; CAB International: Wallingford, UK, 2007.

102. Jia, H.; Wang, N. Targeted genome editing of sweet orange using Cas9/sgRNA. PLoS ONE 2014, 9, e93806. [CrossRef]

103. Zhang, F.; Leblanc, C.; Irish, V.F.; Jacob, Y. Rapid and efficient CRISPR/Cas9 gene editing in Citrus using the YAO promoter. Plant Cell Rep. 2017, 36, 1883-1887. [CrossRef]

104. Jia, H.; Orbovic, V.; Wang, N. CRISPR-LbCas12a-mediated modification of citrus. Plant Biotechnol. J. 2019, 17, 1928-1937. [CrossRef]

105. Zhang, F.; Rossignol, P.; Huang, T.; Wang, Y.; May, A.; Dupont, C.; Orbovic, V.; Irish, V.F. Reprogramming of Stem Cell Activity to Convert Thorns into Branches. Curr. Biol. 2020, 30, 2951-2961.e5. [CrossRef] [PubMed]

106. Zhang, F.; Wang, Y.; Irish, V.F. CENTRORADIALIS maintains shoot meristem indeterminacy by antagonizing THORN IDENTITY1 in Citrus. Curr. Biol. 2021, 31, 2237-2242.e4. [CrossRef] [PubMed] 